\title{
TINJAUAN REALITAS TERHADAP STATUS, PERAN DAN FUNGSI MANUSIA
}

\author{
Mohammad Urfan ${ }^{1)}$ \\ Desy Apriani ${ }^{2)}$ \\ Dedeh Supriyanti ${ }^{3)}$ \\ 1) Institut Teknologi Bandung \\ J1. Tamansari 64, Bandung Jawa Barat \\ ${ }^{2,3)}$ STMIK Raharja Tangerang \\ J1. Jenderal Sudirman No.40 Modern-Cikokol Tangerang
}

\begin{abstract}
ABSTRAK
Al-Qur'an surat 23 Ayat 12-14 menjelaskan proses penciptaan manusia dari nuthfah, berubah menjadi alaqah, mudhghah, izham dan khalqan akhar (makhluk lain). Selanjutnya dijelaskan juga dalam ayat lain seperti (QS:25:54), (QS:86:6-7), (QS:18:37), (QS:32:7), (QS:37:11), (QS:15:26). Dari berbagai ayat diatas dapat di simpulkan bahwa jasad/fisik merupakan salah satu unsur yang ada dalam diri manusia. Namun unsur tersebut memiliki banyak kelemahan. Tujuan penelitian ini adalah untuk mengkaji tiga unsur yang ada dalam diri manusia, serta mengkaji status, peran dan fungsi salah satu unsur terpenting dalam diri manusia, yang menyebabkan manusia bisa dikatakan sebagai makhluq yang sempurna. Metode penelitian ini hanya mengkaji berbagai ayat dalam AlQur'an yang berkaitan dengan manusia, lalu mengarahkan pembaca untuk mempercayai dan meyakini kebenarannya. Hasil dari penelitian ini membuktikan bahwa manusia terdiri dari tiga unsur yaitu jasad (fisik jasmani), ruh, dan nafs/nafsiah (jiwa). Penelitian ini menyimpulkan bahwa nafsiah (jiwa) yang membedakan manusia dengan mahluk lainnya. Nafsiahlah yang dapat membuat manusia menjadi mahluk yang sempurna. Nafsiahlah yang menjadi pelaku dan pengendali kehidupan seseorang di alam dunia ini.
\end{abstract}

Kata Kunci : Manusia, Jasad (Jasmani), Ruh, Nafs (Jiwa), Fujur, Taqwa

\begin{abstract}
In the letter 12-14 Verse 23 of Qoran, it describes the process of creation of human from nuthfah, turned into alaqah, mudhghah, Izham and khalqan akhar (other beings). Further, It has described in other verses like (QS:25:54), (QS:86:6-7), (QS:18:37), (QS:32:7), (QS: 37:11), (QS:15:26). After learning carefully the various verses above, we can conclude that the body / physical is one of element that exists within the human. However, these elements have many weaknesses. The purpose of this study was to examine the three elements that exist in human beings, then we would like to observe carefully about status, role and function of one of the most important elements in humman, which causes humans can be regarded as a perfect creature. The methods of this observation is examines various verses in the Qoran related to human, then we would like to force the reader to trust and believe in the truth. Results of this study prove that human is composed of three elements, namely the bodies (physical materiality), spirit and soul. The study concluded that soul that distinguishes human from other creatures. The soul that can make a human become perfect beings. Soul has been main actors and controllers all of human life in the world.
\end{abstract}

Vol.1 No.1 - Agustus 2015 
Keywords: Human, Physical, Spirit, Soul, Bad Attitude, God-Fearing

\section{A. PENDAHULUAN}

\section{Latar Belakang Masalah}

Manusia merupakan makhluq yang paling sempurna. Semua orang yang merasa manusia tentu sepakat dengan pernyataan ini. Namun parameter yang di gunakan untuk menunjukkan bahwa manusia itu sempurna ternyata berbeda. Sangat banyak ahli dan professor dari berbagai disiplin ilmu menghasilkan penelitian tentang kesempurnaan manusia. Namun jika kita kaji lebih dalam lagi ternyata hasil penelitian tersebut sebagian besar mengarah kepada kesempurnaan fisik jasmani manusia semata.

Sementara fisik jasmani (jasad) hanya mampu bertahan kesempurnaannya tidak lebih dari 60-70 tahun. Setelah itu ia akan lemah, keriput, dan akhirnya ditinggalkan oleh ruh lalu menjadi mayat. Bahkan mayat tersebut akan habis dimakan oleh cacing tanah saat dikubur. Ternyata siklus kehidupan fisik-jasmani (jasad) manusia tersebut sama saja dengan makhluq lainnya, yang akan menjadi bangkai dan habis dimakan oleh cacing tanah. Lantas kemanakah kesempurnaan manusia yang di banggakan tersebut?

Al-Qur'an menjelaskan bahwa secara jasadiyah (fisik-jasmani), manusia sama saja dengan makhluq lainnya seperti kucing, kambing, kerbau, kuda, dan lain-lain. Mengapa demikian?, karena manusia dan makhluq lainnya berasal dari tanah atau saripati yang berasal dari tanah. Mereka mengambil saripati makanan dari tanah, selama hidupnya tidak pernah lepas dari tanah, bahkan selalu memperebutkan sebidang tanah, akhirnya jika mati mereka semua akan kembali ke tanah dan menjadi tanah kembali.
Bahkan manusia merupakan makhluq yang paling rakus diantara binatang/makhluq yang ada di muka bumi ini. Seluruh makhluq bisa dimakan oleh manusia mulai dari sayuran, buahbuahan, biji-bijian, ikan, ayam, kambing, sapi, bahkan ada manusia yang memakan daging manusia. Sebagian ahli mengatakan bahwa manusia memiliki akal untuk mengembangkan teknologi tinggi. Namun sayangnya sebagian teknologi tinggi tersebut (seperti bom atom, bom kimia, dan lain-lain) hanya untuk membunuh sesama manusia dan makhluq lainnya dalam jumlah besar dalam waktu yang sangat singkat. Sebuas-buasnya seekor harimau yang menjadi raja hutan hanya mampu membunuh satu sampai dua orang manusia saja. Akhirnya, terbuktilah dengan akal yang dimilikinya dapat membuat sebagian manusia menjadi makhluq yang lebih kejam dari si raja hutan yang ditakuti tersebut.

Lantas unsur apakah dalam diri manusia yang mampu membuat manusia menjadi makhluq yang sempurna, dan memiliki derajat yang lebih tinggi dari malaikat?, bahkan bangsa jin dan syaithon cemburu dengan kesempurnaan manusia tersebut?

\section{Tujuan Penelitian}

Tujuan penelitian ini adalah untuk mengkaji tiga unsur yang ada dalam diri manusia, serta mengkaji status, peran dan fungsi salah satu unsur terpenting dalam diri manusia, yang menyebabkan manusia bisa dikatakan sebagai makhluq yang sempurna. Metode penelitian ini hanya mengkaji berbagai ayat dalam Al-Qur'an yang berkaitan dengan manusia, lalu mengarahkan pembaca untuk mempercayai dan meyakini kebenarannya. 


\section{B. ANALISA TERHADAP STATUS, PERAN DAN FUNGSI BERBAGAI UNSUR DALAM DIRI MANUSIA}

Manusia secara umum termasuk dalam kategori mahluk hidup yang berjenis mamalia. Teori Barat (kaum materialisme) menyamakan manusia seperti hewan. Darwin (1809-1882) menyatakan bahwa manusia adalah bentuk akhir dari pada evolusi hayati, sedang hewan bersel satu sebagai awal evolusi. Manusia adalah hasil evolusi dari bentuk kera. Thomas Hobbes (15881679) menyatakan bahwa sifat dan tabiat manusia sama dengan binatang dalam teori sosiologinya adalah homo homini lupus (manusia yang satu adalah srigala buat manusia lainnya). Semua teori diatas hanya membahas manusia dari segi jasadiyah (fisik-jasmani) semata, sementara tidak ada yang membahas dari segi nafsiyah (nafs/jiwa).

Berdasarkan berbagai teori diatas, maka dewasa ini sudah berkembang pendapat yang hampir diyakini oleh semua umat manusia, yang mengatakan bahwa manusia adalah makhluq yang paling sempurna. Kesempurnaan manusia itu diukur dari kemampuannya dalam menundukkan alam, mengembangkan teknologi berat dan tepat guna, serta mampu membuat berbagai aneka resep makanan.

Bahkan hari ini kesempurnaan manusia selalu di ukur dari seberapa ahlinya dia menguasai teknologi maju, misalnya bisa membuat nuklir, menciptakan pesawat luar angkasa, menggunakan perangkat teknologi informasi untuk memenuhi berbagai kebutuhan hidupnya, Ada lagi yang mengukur kesempurnaan manusia karena telah mampu menjadi Miss. Indonesia, atau Miss.Universe, karena untuk menjadi yang seperti itu manusia harus memiliki kesempurnaan emosional, phisikologis, intelektual, cantik dan rupawan, serta memiliki inner beauty.
Ternyata semua pernyataan diatas sedikitpun tidak menunjukkan kesempurnaan manusia dan belum tentu sesuai dengan realita yang ada. Mengapa? kalau manusia sempurna hanya diukur karena telah menjadi Miss. Universe hal itu salah besar, karena yang menilai si Miss Universe cantik dan sempurna hanya manusia saja, kucing, monyet, kambing, ayam tidak menjadi juri dalam miss universe. Karena kalau penilaian sesama manusia, lalu ada manusia yang cantik dan ganteng menurut manusia juga ya wajar saja. Penilaian tersebut biasa-biasa saja, lalu manusia yang katanya sempurna/ganteng/cantik tersebut juga bukanlah manusia yang sempurna alias biasa-biasa saja.

Mengapa? Sama saja dengan kucing, pada dasarnya ada kucing yang ganteng dan cantik jika yang menilai sesama kucing. Ada juga kambing betina yang sangat cantik rupawan menurut kambing jantan, karena yang menilai sesama kambing. Ada juga monyet jantan yang sangat ganteng dan maco menurut monyet betina, karena penilaian sesama monyet.

Dari segi makanan manusia sangatlah tidak sempurna, bahkan manusia adalah makhluq yang paling rakus diantara semua makhluq yang ada. Sebab banyak sekali makanan yang bisa dimakan oleh manusia, beda halnya dengan kambing yang hanya makan dedaunan, kambing tidak pernah makan daging sapi, ayam yang hanya makan biji-bijian, ayam tidak pernah makan daging bebek, dan lain-lain.

Dari segi kasih sayang, semua binatang juga memiliki rasa kasih sayang yang sama dengan manusia, seperti kucing, ayam, kambing, monyet, dan lain-lain. Bahkan semua binatang lebih hebat lagi, mereka tidak pernah sekolah sampai menjadi sarjana, tidak pernah belajar komputer, tidak punya asuransi pendidikan, namun mereka tetap 
memperoleh jatah rizki yang berlimpah dari Allah. Mereka tidak pernah takut punya anak banyak, mereka tidak ada yang ikut program Keluarga Berencana, namun tidak ada satu binatangpun yang takut tidak bisa dapat makan atau anaknya akan mati kelaparan, walaupun mereka sang binatang tersebut tidak pernah sekolah, tidak pernah bekerja menjadi karyawan tetap yang pasti mendapat gaji setiap bulan.

\section{PEMBAHASAN}

\section{Asal Usul Manusia}

Manusia adalah makhluq yang lemah, bodoh, dan sangat banyak kekurangannya, sehingga sampai kapanpun tidak akan mampu membuat teori tentang dirinya sendiri, walau sehebat apapun manusia itu.

Dalam logika sederhana, dapat dipahami bahwa yang paling mengerti tentang penciptaan manusia hanyalah sang pencipta itu sendiri, Allah merupakan sang maha pencipta. Jadi hanya Allah yang memahami tentang proses penciptaan manusia. Dalam AlQur'an di jelaskan tentang proses penciptaan manusia, antara lain dalam surat 23 Ayat 12,13 dan 14, yang artinya, "Dan Sesungguhnya kami telah menciptakan manusia dari suatu saripati (berasal) dari tanah. Kemudian kami jadikan saripati itu air mani (yang disimpan) dalam tempat yang kokoh (rahim). Kemudian air mani itu kami jadikan segumpal darah, lalu segumpal darah itu kami jadikan segumpal daging, dan segumpal daging itu kami jadikan tulang belulang, lalu tulang belulang itu kami bungkus dengan daging. Kemudian kami jadikan dia makhluk yang (berbentuk) lain. Maka Maha sucilah Allah, Pencipta yang paling baik".

Ayat tersebut menjelaskan tentang asal penciptaan manusia dari "sulatin minthin (sari pati tanah)". Kata sulatin dapat diartikan dengan hasil akhir dari sesuatu yang disarikan, sedangkan thin berarti tanah. Pada tahap berikutnya saripati tanah berproses manjadi nuthfah (air mani).

Pada ayat 14 dijelaskan tentang tahapan reproduksi manusia setelah nuthfah, perubahan nuthfah secara berturut-turut menjadi 'alaqah, mudhghah, izham dan khalqan akhar (makhluk lain). 'Alaqah memiliki dua pengertian, pertama darah yang mengental sebagai kelanjutan dari nuthfah, kedua sesuatu yang menempel di dinding rahim. Mudhghah berarti sebuah daging yang merupakan proses penciptaan manusia sebagai kelanjutan alaqah. Izham (tulang-belulang) selanjutnya dibalut dengan lahm (daging). Pada fase ini sampai pada pencapaian kesempurnaan bentuk manusia yang disebut dengan khalqon akhar, berarti ciptaan baru yang jauh berbeda dengan keadaan dan bentuk sebelumnya. Selanjutnya Al-Qur'an juga mengatakan dalam beberapa ayatnya tentang proses penciptaan manusia, seperti (QS:25:54), (QS:86:6-7), (QS:18:37), (QS:32:7), (QS:37:11), (QS:15:26).

Dari berbagai ayat diatas dapat di simpulkan bahwa jasad (fisik-jasmani) merupakan salah satu unsur yang ada dalam diri manusia. Namun unsur tersebut bukanlah yang utama dalam diri manusia. Mengapa? Karena jasad (fisikjasmani) memiliki banyak kelemahan dan umurnya singkat, seorang manusia dikatakan cantik/ganteng, dikatakan perkasa, pintar genius, hanya sampai umur maksimal 60 tahun, setelah itu sudah keriput, bahkan ada yang sudah pikun, sudah pakai tongkat.

Bahkan menurut Al-Qur'an jasad/fisik yang cantik/ganteng dan genius tersebut, hanyalah berasal dari setetes air yang hina. Jasad/fisik tersebut memiliki unsur yang semuanya berasal dari tanah, dan jika mati/meninggal dunia 
lalu dikubur, akan kembali kepada tanah lagi, kecantikan dan kejeniusannya sudah tidak bersisa lagi, sudah menyatu juga dengan tanah.

\section{Unsur Apakah Yang Membuat Manusia Sebagai Makhluq Yang Sempurna?}

Allah SWT berfirman dalam surat Al-Jumu'ah Ayat 2, "Dia-lah (Allah) yang mengutus kepada kaum yang buta huruf seorang rosul diantara mereka, yang membacakan ayat-ayat-Nya kepada mereka, menyucikan mereka dan mengajarkan mereka Al-Kitab dan AlHikmah. Dan sesungguhnya mereka sebelumnya benar-benar dalam kesesatan yang nyata.". Allah SWT juga berfirman dalam surat Al-Baqarah Ayat 151, "Sebagaimana (Kami telah menyempurnakan nikmat Kami kepadamu), Kami telah mengutus kepadamu rasul diantara kamu yang membacakan ayat-ayat Kami kepada kamu dan menyucikan kamu dan mengajarkan kepadamu Al-Kitab dan AlHikmah, serta mengajarkan kepada kamu apa yang belum kamu ketahui."

Dari kedua ayat diatas, kita bisa mengetahui bahwa tugas Rasulullah Saw ada tiga. Pertama, tilawatul aayaat : membacakan ayat-ayat Allah (AlQur'an). Kedua, tazkiyatun nafs: menyucikan jiwa. Dan ketiga, ta'limul kitaab wal hikmah: mengajarkan kitabullah dan hikmah. Sehingga tugas setiap nabi dan rosul tersebut bukan untuk mengurus jasad/fisik, melainkan memaksimalkan potensi jasad/fisik dalam beribadah kepada Allah, karena kita hidup di alam tasyri

\section{Manusia Ditinjau Dari Unsur Ruh (Ruhiah)}

Unsur kedua dalam diri manusia adalah ruh (ciptaan-Nya), yang ditiupkan ke dalam rahim wanita yang mengandung embrio yang terbentuk dari saripati (zat) tanah itu. Hanya sedikit pengetahuan manusia tentang ruh, "Dan (ingatlah), ketika Tuhanmu berfirman kepada para malaikat, "Sesungguhnya Aku akan menciptakan seorang manusia dari tanah liat kering yang berasal dari lumpur hitam yang diberi bentuk. Maka, apabila Aku telah menyempurnakan kejadiannya, dan telah meniupkan ke dalamnya ruh (ciptaan) Ku, maka tunduklah kamu kepadanya dengan bersujud" (QS:15:2829)". Yang dimaksud "dengan bersujud" dalam ayat ini bukanlah menyembah, tetapi memberi penghormatan.

Al-Qur'an tidak memberi penjelasan tentang sifat ruh, Allah berfirman dalam surat Al-Isra' Ayat 85 yang artinya, "Mereka bertanya kepadamu (Muhammad) tentang ruh. Katakanlah (kepada mereka) bahwa ruh itu adalah urusan Tuhanku dan kamu tidak diberi pengetahuan kecuali hanya sedikit". Firman Allah itu menunjukkan bahwa masalah ruh adalah urusan Tuhan sendiri dan akal manusia terlalu picik untuk memikirkannya, serta memahami kenyataan yang gaib mutlak tersebut.

Semua makhluq hidup akan memiliki ruh, seperti manusia, kucing, kambing, ayam, monyet, dan lain-lain. Ruh setiap mahluk hidup akan kembali kepada Allah setelah mahluk tersebut mati atau di cabut nyawanya (ruhnya). Semua manusia baik Islam maupun diluar Islam memiliki ruh yang sama dari Allah, dan akan kembali kepada Allah ruh tersebut, setelah maninggal dunia.

Berdasarkan penjelasan diatas, maka terlihat bahwa jasad dan ruh merupakan unsur yang dimiliki oleh semua mahlik hidup termasuk manusia, namun ada satu unsur yang tidak dimiliki oleh mahluk lain, hanya dimiliki oleh manusia, yaitu nafsiah (nafs/jiwa).

\section{Manusia Ditinjau Dari Unsur Nafsiah (Nafs/Jiwa)}


Berbeda dengan kedua unsur sebelumnya, nafsiah (nafs/jiwa) adalah unsur yang banyak diterangkan dalam $\mathrm{Al}$ Qur'an. Nafsiah ini yang menjadi khitob setiap kali Al-Qur'an berbicara tentang manusia. Karen anfusiyah inilah yang merupakan unsur hakiki dari manusia. Firman Allah yang artinya, "....Kemudian Dia menyempurnakan dan meniupkan kedalam (jasad)nya ruh-Nya, dan dijadikannya bagi kamu pendengaran, penglihatan dan hati, tetapi kamu sedikit sekali bersyukur" (QS:32:9). Dalam ayat ini dijelaskan proses pembentukan jasad manusia. Ketika proses jasmani telah sempurna terbentuk, maka ditiupkanlah ruh kedalamya, setelah itu dijadikannya sam'a, abshor, dan af 'idah.

Sam'a (pendengaran), abshor (penglihatan) dan af'idah (hati) inilah yang disebut (potensi-potensi) Nafsiah. Sam'a, abshor, af'idah tersebut bukan sifat atau potensi yang melekat pada jasmani maupun ruhani, tetapi potensipotensi yang dimiliki oleh nafs (jiwa).

Nafs dengan potensi-potensinya adalah sesuatu yang berbeda dengan unsur jasmani dan ruhani. Walaupun unsur nafsiah (nafs/jiwa) ini berada didalam wadah jasmani, namun ia bukan menjadi bagian dari jasmani atau sesuatu yang melebur kedalam unsur jasmani, melainkan suatu unsur yang terpisah (mandiri), dan memiliki eksitensi tersendiri yang hakekatnya berbeda dari jasmani maupun ruhani.

Unsur nafsiah ini tidak dimiliki oleh makhluk lain kecuali manusia. Adanya unsur nafsiah inilah yang menyebakan eksistensi manusia berbeda dengan eksistensi makhluk hidup lain. Sedangkan hewan dan tumbuh-tumbuhan karena tidak memiliki nafsiah, maka keberadaannya tidak memiliki posisi sentral dalam kehidupan di alam semesta ini.

Hewan dan tumbuh-tumbuhan (hayanawat dan nabatat) tidak memiliki potensipotensi nafsiah (sam'a, abshor dan $\left.a f^{\prime \prime} i d a h\right)$ seperti yang dimiliki oleh manusia, sehingga hewan dan tetumbuhan tidak memiliki kemampuan untuk menerima, merespon dan mengendalikan kehidupannya. Hewan dan tumbuh-tumbuhan tidak memiliki kecenderungan untuk berbuat fujur dan taqwa, serta tidak memiliki kecendrungan aqal dan hawa yang akan menguasai dirinya. Karena fujur dan taqwa, aqal dan hawa adalah sifat-sifat nafsiah.

Oleh karena itu hewan dan tumbuhan tidak memiliki misi dan tanggung jawab yang harus diemban dalam kehidupannya. Lebih jauhnya mereka tidak memiliki potensi untuk melaksanakan amanah-amanah Allah. Hanya nafsiahlah yang mampu mewujudkan misi amanah tersbut.

Kehidupan hewan dan tumbuhtumbuhan tidak lebih hanya untuk memenuhi kebutuhan-kebutuhan fisikjasmaniyahnya semata, hidupnya tidak lain hanya untuk menjalani dan mempertahankan hidup agar tidak mati, tidak lebih dari itu. Namun demikian itulah bentuk pengabdian mereka terhadap Allah. Sehingga hewan dan tumbuhan tidak dimintai pertanggung jawabannya di sisi Allah kelak.

Sedangkan manusia karena memiliki satu unsur yang berbeda dari binatang dan tetumbuhan tersebut, maka perjalanan hidupnya pun sangat berbeda. Kehidupan manusia tidak hanya untuk memenuhi kebutuhan fisikjasmaniyahnya saja agar dapat hidup, tumbuh dan berkembang biak seperti hewan dan tumbuh-tumbuhan, tetapi manusia harus mampu merespon dan mengendalikan kehidupannya sesuai dengan kecenderungan nafsiahnya. Kehidupan manusia sangat tergantung pada pejalanan nafsiahnya. Itulah sebabnya mengapa kehidupan manusia berbeda dengan kehidupan hewan dan tumbuh-tumbuhan. 
Kehidupan manusia akan berbeda dengan kehidupan hewan dan tumbuhtumbuhan, jika nafsiah dari manusia tersebut hidup, namun akan menjadi sebaliknya, jika nafsiah manusia (orang) tersebut mati. Mengapa ? Karena ketika nafsiah seseorang "mati" maka tidak ada lagi yang dapat membedakan eksistensinya dengan binatang maupun tetumbuhan, bahkan kondisi manusia yang seperti itu jauh lebih hina dan sesat dari binatang sekalipun.

Unsur nafsiah akan diberikan oleh Allah kepada setiap manusia setelah ditiupkannya Ruh. Nafsiah-lah yang membuat perjanjian dihadapan Allah. Dalam QS:7:172 menjelaskan tentang peristiwa syahadah ("pesaksian") yang dilakukan nafsiah ketika di alam rahim. Peristiwa ini terjadi di alam takwin atau alam sebelum manusia dilahirkan ke alam dunia. Nafsiah yang memberi persaksian tentang kerububiyahan Allah.

Saat lahir ke alam dunia jasad dan nafsiah manusia dalam keadaan fitrah/suci, walaupun ia dilahirkan dari rahim ibu yang anti Islam sekalipun. Orang tua, lingkungan dan sistem pemerintahan yang dapat merubah atau mempertahankan kehidupan/fitrah nafsiah tersebut.

Jasad/fisik akan tumbuh dan berkembang sesuai dengan kodratnya, jika di berikan pasokan makanan yang sesuai dengan kebutuhannya, yaitu: nasi, sayuran, buah-buahan, pendidikan matematika, pendidikan psikologi, pendidikan teologi, dll, maka jasad/fisik manusia akan tumbuh dan berkembang dengan baik, dan akan menjadi jasad yang baik/berhasil seperti menjadi guru, menjadi pengusaha, menjadi teknokrat, menjadi psikolog, dll.

Begitu juga sebaliknya dengan nafsiah, sejak lahir harus di pertahankan dan di berikan pasokan makanan yang sesuai juga dengan kebutuhannya. Makanan untuk nafsiah adalah dzikrullah, ibadah, mendengar dan mengkaji ayat-ayat Allah, mengkaji nilainilai keislaman. Jika sejak lahir nafsiah juga selalu mendapatkan pasokan yang sesuai, maka nafsiah akan tumbuh berkembang seperti jasad, dan menjadi nafsiah yang sempurna, yaitu menjadi manusia-manusia yang sholeh, tawadhu, selalu bersyukur, dan menjadi manusia yang muttaqien.

Jika pasokan makanan untuk nafsiah kurang (jarang sekali berinteraksi dengan nilai-nilai Islam), sementara pasokan makanan untuk jasadiah cukup, maka pertumbuhannya tidak seimbang, dalam istilah lain dalam Al-Qur'an sering disebut dengan hati yang sakit. Sehingga bisa saja ditemukan manusia dengan jasad berumur 24 tahun, namun nafsiahnya bisa saja masih kecil/sedang sakit, sehingga manusia seperti ini tidak merasa malu jika tidak menutup auratnya di tempat-tempat umum, manusia seperti ini masih banyak melanggar perintah Allah, masih banyak berbuat dosa, dan maksiat. Seperti ada ungkapan, "kok sudah dewasa tidak malu ya keluar rumah tidak memakai jilbab?, "kok sudah dewasa masih saja berbuat maksiat?. Inilah beberapa contoh manusia yang jasadnya (fisikjasmaninya) sehat-segar bugar, cantik atau ganteng, namun nafsiah-nya masih kecil atau sedang sakit, sehingga tidak merasa berdosa melanggar perintah Allah. Sakit hati (hati yang sakit) dalam bentuk nafsiah (jiwa) seperti inilah yang sangat berbahaya, karena nanti akan dimintai pertanggung jawabannya oleh Allah kelak di yaumil akhir.

Jika sejak lahir pasokan makanan untuk nafsiah tidak pernah di berikan, maka lama kelamaan nafsiah akan sakit, bahkan nafsiah seseorang bisa mati jika tidak mendapat makanan yang sesuai dengan kebutuhannya, dalam istilah AlQur'an adalah Qalbun Mayyit.

Inilah contoh mereka yang berada diluar Islam dan tidak mau menerima da'wah Islam, karena nafsiahnya sudah 
mati. Manusia seperti ini di katakan hidup, hanya karena masih ada ruh di dalam jasadnya, namun perilakunya tidak jauh berbeda dengan binatang. Manusia seperti ini akan selalu berbuat dosa, selalu bermaksiat kepada Allah, selalu melanggar perintah Allah, bahkan berani menantang Allah dengan berbuat dosa sebanyak mungkin, selalu berzinah, membunuh, memfitnah, dll.

Ketika unsur yang membedakan manusia dengan binatang tidak ada atau ketika nafsiah seseorang telah mati, dan dikendalikan oleh hawa nafsunya, maka kehidupan yang dibangun oleh orang tersebut tidak lebih mulia dari aktivitas kehidupan binatang. Bahkan akan terjadi kerusakan, kehancuran, dan kebinasaan yang akan menimpanya sebagai akibat dari hilangnya unsur hakiki dari kemanusiaannya.

Kalau binatang hidupnya hanya memenuhi kebutuhan jasmani agar ia dapat hidup, sedangkan manusia yang telah jatuh derajatnya dibawah binatang akan menjadikan seluruh hidup dan kehidupannya hanya untuk memenuhi kebutuhan jasmani dan hawa nafsunya, dan seluruh potensi yang ia miliki akan dikerahkan dan diorientasikan untuk mencapai tujuan tersebut.

Lantas mengapa usur nafsiah dikatakan sebagai unsur hakiki manusia? Dimana semua kehidupan manusia di dunia ini bergantung pada nafsiah tersebut?. Dan bagaimana kaitan atau hubungan antara unsur nafsiah tersebut dengan unsur-unsur lainnya (jasmani dan ruhani)?

Dalam Al-Qur'an menjelaskan bahwa Allah telah mengilhamkan kedalam jiwa dua jalan yakni fujur dan taqwa, "Dan demi jiwa serta penyempurnaannya. Makaallah mengilhamkan kepada jiwa itu jalan kefajiran dan ketaqwaan. Sesungguhnya beruntunglah orang yang menyucikan jiwanya. Dan sesungguhnya merugilah orang yang mengotorinya". (QS:91:7-10)
Ayat tersebut menjelaskan bahwa dalam nafsiah ini terdapat dua kecenderungan; pertama yang bersifat positif (taqwa) dan kedua yang bersifat negatif (fujur). Dengan demikian nafsiah manusia bisa terjerumus ke dalam kefajiran atau sebaliknya mencapai ketaqwaan. Nafsiah manusia selalu berada diantara tarik menariknya antara fujur dan taqwa. Itulah sebabnya mengapa tidak setiap manusia berbuat taqwa dan tidak seluruh manusia berbuat fujur. Setiap manusia memiliki kecenderungan untuk berbuat jahat, nista, aniaya atau sebaliknya berpotensi untuk berbuat baik, jujur, adil dan lain-lain.

Sedangkan fujur atau taqwanya nafsiah tersebut tergantunng pada sejauh mana perebutan antara aqal dan hawa. Jika aqal dapat mendominasi dan menguasai diri seseorang, maka ia akan cenderung kepada taqwa, sebaliknya jika yang mendominasi nafsiah adalah hawa, maka ia akan cenderung kepada fujur dalam sebuah hadits disebutkan, "Thuba liman kama aqluhu amiron wahawahu asyiron, wal wadu liman kama aqluhu asiron wahawahu amiiron", yang artinya "Berbahagialah bagi seseorang yang akalnya menjadi pimpinan dan hawanya sebagai tawanan, dan celakalah bagi seseorang yang akalnya menjadi tawanan dan hawanya menjadi pimpinan".

Aqal adalah lawan dari hawa. Kalau sifat hawa adalah cenderung kepada fujur (negatif), sedangkan aqal cenderung kepada taqwa (positif). Nafsiah yang dikuasai oleh aqal adalah nafsiah yang hidup. Tumbuh dan berkembang. Sabaliknya jika hawa yang menguasai nafsiah maka potensi-potensi nafsiah adalah kematian.

Sedangkan nafsiah yang dikuasai oleh hawa adalah nafsiah yang "mati". Nafsiah yang mati ditandai dengan tidak berfungsinya potensi sam'a (pnglihatan), abshor (pendengaran), dan af'idah (hati), artinya ia tidak mampu lagi 
melihat mendengar dan mengetahui yang mana al-haq dan yang mana al-bathil, mana tujuan dan tugas serta tanggung jawab hidup sebenarnya yang harus ia laksanakan.

Jika hawa yang telah mendominasi nafsiahnya, maka segala tujuan, orientasi, dan aktivitas hidupnya tidak lain hanya untuk kepentingan hawa nafsunya tesebut. Hidup dan kehidupannya tidak lain hanya karena tidak mati saja, perilakunya menjadi seperti binatang, bahkan lebih sesat dan hina dari itu. QS:7:179 dan QS:6:39,25 menggambarkan tentang orang kafir, yakni manusia yang potensi-potensi nafsiahnya telah mati (tidak berfugsi), penglihatan, pendengaran, dan hatinya telah tertutup. Sehingga ia tidak lagi mampu merespon terhadap keadaankeadaan yang dihadapinya. Tetapi sebaliknya keadaan atau alam fisiknyalah yang mengendalikan nafsiahnya.

Akhirnya ia terjebak dalam kungkungan alam duniawi yang mengikatnya, dan tidak mampu membebaskan dan melepaskan nafsiahnya dari belenggu tersebut. Ketika nafsiah seseorang telah mati, maka akibatnya ia tidak lagi memiliki perhatian dan keperdulian terhadap nilainilai kebaikan, kebenaran, kemuliaan, kesejahteraan dan lain-lain, yang semua itu sesungguhnya adalah kebutuhan hakiki dirinya.

Agar nafsiah ini dapat hidup dan berkembang, maka ia harus mendapat konsumsi. Konsumsi nafsiah jelas tidak sama denagn konsumsi jasmani. Kalau konsumsi jasmani bersumber dari alam (bumi/tanah), sementara nafsiah karena ia bukan bersifat material, maka konsumsi nafsiah tidak dapat dipenuhi dari alam (bumi). Konsumsi nafsiah hanya dapat dipenuhi oleh Dinul qoyyim (Din Islam).

Dinul qoyyim ini berasal dari potensi keimanan dan keislaman, sehingga pada hakekatnya setiap manusia cenderung membedakan memilih dan memilah mana yang baik, dan mana yang buruk. Hal-hal apa saja yang akan merugikan dan mencelakakan. Serta halhal apa saja yang akan membahagiakan dan mensejahterakan diriya, mana jalan yang harus ia ikuti dan taati serta mana jalan yang harus ia jauhi dan tinggalkan. Nafsiah yang hidup mampu mengedalikan dan mengontrol hawanya, sehinga ia akan terpelihara dari sifat-sifat kefajiran.

Sebaliknya, jika nafisah ini tidak mendapat konsumsi yang sesuai dengan hakekatnya, maka lambat laun secara bertahap ia akan mengalami "kematian". Ketika nafsiah tidak mendapat konsumsi dinul islam, maka hawaniyah yang menjadi konsumsinya, maka nafsiah tersebut terus menerus meneima makanan yang diberikan oleh hawa, sehingga akhirnya ia pun akan menolak jika diberi kosumsi dinul islam.

Karena nafsiah adalah hakekat/unsur terpenting dari manusia itu sendiri, maka dapat dipahami mengapa Allah menilai seseorang dari nafsiahnya, bukan dari segi fisik jasmaniyah seperti ditegasan dalam hadits yang artinya, "Sesungguhnya Allah tidak melihat bentuk wajahmu dan tidak pula tubuhmu, akan tetapi Allah melihat ini, hatimu dan perbuatanmu".

Mengapa demikian? Karena dalam hal fisik-jasmani seiap manusia telah ditentukan oleh Allah sejak awal proses penciptaannya, sehingga seseorang tidak bisa menolak atau mengelak terhadap wujud jasmaninya sendiri, apakah ia berjenis kelamin wanita atau laki-laki, berkulit hitam atau bule, hidung mancung atau pesek, berambut pirang atau hitam, keturunan asia atau Afika atau Amerika dan lain sebaginya.

Semua itu adalah mutlak ketentuan Allah semata, dan diluar dari kehendak manusia itu sendiri. Karena masalah jasmani adalah ketetapan Allah semata, maka setiap manusia tidak memiliki 
kemampuan dan kekuatan sedikitpun untuk merubah atau menggantinya. Oleh karena itu, Allah tidak menilai manusia dari segi jasmani yang memang telah ditetapkan-Nya, tetapi Allah akan menilai kepada hati dan amaliyah orang tersebut, karena perkembangan dan pertumbuhan hati serta banyaknya amal seseorang adalah tergantung pada orang tersebut.

Tertutup tidaknya hati (qolbu) dan banyak atau sedikitnya amal, bukan sesuatu yang telah Allah tetapkan pada diri sseorang sejak lahir, akan tetapi semua itu tergantung pada sejauh mana orang tersebut berusaha untuk menghidupkan hatinya (potesi nafsiah), serta memperbanyak amal ibadahnya selama ia hidup di alam dunia ini. Yang dimaksud hati (qolbu) dalam hadits tersebut jelas bukan hati jasmani, tetapi hati nafsiah (jiwa), kaena hanya hati nafsiah-lah yang dapat mendorong seseorang untuk beramal ibadah di sisi Allah.

\section{KESIMPULAN}

Berdasarkan uraian diatas, maka dapat di simpulkan bahwa nafsiahlah yang membedakan manusia dengan mahluk lainnya. Jasad dan fisik manusia secara unsur bumi sama dengan mahluk lainnya. Ruh yang dimiliki oleh manusia berasal dari Allah dan akan kembali kepada Allah.

Nafsiahlah yang membuat manusia menjadi mahluk yang sempurna. Jika seseorang mampu mengendalikan nafsiahnya, maka nafsiah tersebut akan menggerakkan anggota tubuh seperti tangan, kaki, mata, dll untuk mengerjakan perintah Allah. Sebaliknya orang yang menempatkan hawa-nya menjadi pemimpin, maka nafsiahnya akan menggerakkan seluruh anggota tubuh seperti tangan, kaki, mata, dll untuk berbuat maksiat dan berbuat dosa kepada Allah.
Nafsiah adalah unsur yang terpenting dalam diri manusia, nafsiahlah yang menjadi pelaku dan pengendali kehidupan seseorang di alam dunia ini, maka nafsiah ini pula yang akan mengalami kematian. Dalam QS:3:185 disebutkan bahwa setiap yang berjiwa (nafsiah) akan mengalami kematian. Tentang nafsiah yang mengalami kematian ini juga dapat dilihat dalam ayat lain dimana yang mengalami kematian bukan ruh atau jasmani tetapi anfus (jiwa) manusia.

Beberapa ayat dalam Al-Qur'an melukiskan keadaan orang dzolim pada saat menghadapi sakaratul maut. Ketika itu para malaikat mencabut nyawa orang tersebut dengan tangannya sambil berkata "akhrijuu anfusakum" (keluarkanlah jiwamu). Sedangkan yang diperintahkan untuk keluar dari jasad tersebut adalah nafsiah. Bagi orang yang dzalim akan merasakan kematian dengan sangat menyakitkan.

Sebaliknya, bagi orang yang beriman, yakni orang yang mampu menghidupkan dan menumbuhkembangkan nafsiahnya dengan baik akan merasakan kematian dengan penuh kemudahan dan ketenangan, seperti di lukisan dalam QS:89:27-30.

Nafsiah ini pula yang akan merasakan balasan nanti di akhirat kelak. Dihadapan Allah kelak mulut akan terkunci, tidak bisa melakukan pembelaan. Seluruh anggota tubuh secara fisik-jasmani yang akan bersaksi dihadapan Allah. Tangan, kaki, mata hidung, mulut, telinga akan bersaksi dihadapan Allah, bagaimana nafsiah menggerakkannya untuk melakukan berbagai perbuatan baik atau buruk. Pada hari itu Allah akan membalas mereka sesuai dengan amaliyah yang mereka lakukan selama hidup di dunia. 


\section{DAFTAR PUSTAKA}

Abdullah bin Muhammad Al-Muthlaq, Dr,"Husnul Khotimah wasailuha Wa 'Alamatuha wat Tahdziru Min Suil Khotimah", Buletin Da'wah, Daar AlWathan-Riyadh No.73, 2004

Abdullah Gymnastiar,KH, "Menggapai Hidup Berkah", Kumpulan Tausiyah, 2006

Al-Bahra, Ust, Ir, M.Kom, "Penjelasan Surat Yaa Siin (Panduan Yaa Siin dan Tahlil Modern-Buku-2)", STMIK Muhammadiyah Jakarta Press, Jakarta, 2009

Al-Qur'an dan Terjemahnya (Al-'Aliyy), Departemen Agama RI, CV. Penerbit Diponegoro, Bandung, 2005

Asy-Syekh Hamami Zadah,"Tafsir Surat Yaa Siin", diterjemahkan oleh M. Aqiel Asrori, Karya Agung, Surabaya, 2002

Khalid bin Abdul Rahman asySyayi,"Husnul Khatimah wa Su'ul Khatimah", hal: 11-16, Diterjemahkan oleh 'Ammu Khansa 'Arba'in, 2004

Rikza Maulan, Lc., M.Ag, “Ma'rifatul Qur'an', Kumpulan Tausiyah, 2006 